\title{
POSSIBILITIES OF TURNING PASSIVE RURAL AREAS INTO TOURIST ATTRACTIONS THROUGH ATTAINED SERVICE QUALITY
}

\author{
Tamara Gajić ${ }^{1}$, Marko D. Petrović², Milan M. Radovanović 3 , \\ Tatiana N. Tretiakova ${ }^{4}$, Julia A. Syromiatnikova ${ }^{5}$
}

\footnotetext{
1 PhD Tamara Gajić, Senior research, South Ural State University, Institute of Sports, Tourism and Service, Chelyabinsk, Russia; Professor, Novi Sad Business School, Serbia, e-mail: tamara.gajic.1977@gmail.com, ORCID: 0000-0003-3016-8368

2 PhD Marko D. Petrović, Research Associate, Geographical Institute "Jovan Cvijić" SASA, Belgrade, Serbia; Professor, South Ural State University, Institute of Sports, Tourism and Service, Chelyabinsk, Russia, e-mail: m.petrovic@gi.sanu.ac.rs., ORCID: 0000-0002-6561-0307

${ }^{3}$ PhD Milan Radovanović, Principal Research Fellow, Geographical Institute "Jovan Cvijić" SASA, Djure Jakšića 9, Belgrade 11000, Serbia; Professor, South Ural State University, Institute of Sports, Tourism and Service, Chelyabinsk, Russia, email: m.radovanovic@gi.sanu.ac.rs., ORCID: 0000-0002-9702-3879

${ }^{4} \mathrm{PhD}$ Tatiana N. Tretiakova, South Ural State University, Institute of Sports, Tourism and Service, Chelyabinsk, Russia, e-mail: ttn1@mail.ru, ORCID: 0000-0002-3525-5121

${ }^{5} \mathrm{PhD}$ Julia A. Syromiatnikova, Associate Professor, South Ural State University, Institute of Sports, Tourism and Service, Chelyabinsk, Russia, email: syromjatnikowa@mail.ru, ORCID: 0000-0003-3375-3909
} 


\begin{abstract}
This paper gives an overview of the quality of tourism service in rural areas of the South Bačka District, one of the most economically developed parts of Serbia. The main objective of the research is to determine the correlation between the expected and perceived values of the quality of service by collecting and processing data. The modified SERVQUAL questionnaire was applied in the study, and all obtained data were analyzed in the SPSS software 23.00. As a result of the survey, it was found that tourists had significantly higher expectations than perceived service. The results obtained can serve for broader thematic research and contribute to the definition of appropriate corrective actions to improve the quality of tourism services in the selected rural area. Moreover, these are the key propositions to start an initiative for the improvement of tourism services in any undeveloped rural setting with a tourism offer. The results provide tourism organizers and local authorities with important visitors' perpceptions pertaining to the quality of rural tourism service.
\end{abstract}

Key words: rural development, tourism, South Bačka, service quality

Апстракт: У овом раду дат је приказ квалитета туристичке услуге у руралним областима Јужнобачког округа, који припада једном од развијенијих делова Србије. Основни циљ истраживања јесте да се прикупљањем и обрадом података, утврди корелација између очекиваних и перципираних вредности квалитета услуге. У истраживању је примењен модификовани SERVQUAL упитник, а сви добијени подаци анализирани су у програмском софтверу СПСС, верзија 23.00. Као резултат истраживања, утврђено је да су туристи у значајној мери имали већа очекивања од перципиране услуге. Добијени резултати могу да послуже за шира тематска истраживања, те да допринесу дефинисању одговарајућих корективних активности ради унапређења квалитета туристичке услуге у Јужнобачком округу.

Кључне речи: рурални развој, туризам, Јужна Бачка, квалитет услуге

\title{
1. Introduction
}

Rural tourism development is a topical issue in the world, as well as in Serbia. The biggest problem that Serbia faces is certainly the quality of service. Quality is a determinant of rural tourism development, or better placement in the tourism market. Tourism demand for peace, rest and recreation in rural areas is a growing trend globally. An important component of rural development and revitalization may be tourism in rural areas, as nowadays, there is a need for new tourism products and experiences, especially for the more solvent and tourism-experienced tourism participants. One of the goals of tourism in rural areas is to provide economic profit to the local population, or extra income, thus improving the quality of life and stopping the abandonment of property and habitats and eviction to urban areas, more precisely to solve the imbalance that is very visible in the village city, in recent decades (Gajic et al, 2018). Rural areas in Serbia cover about $85 \%$ of the territory, with about $44 \%$ of the total population. Given that the statistics on rural development capacity in Serbia are based on estimates, it is assumed that a significant part of overnight stays in spa and mountain areas can also be treated as overnight stays in the area of rural tourism supply (Petrović et al., 2018). Considering the general state of rural development in Serbia, it can be noticed that there are a number of limiting factors that determine the unenviable position of this product on the tourist market. Some of them are: insufficient knowledge of new approaches to developing rural economies in a competitive domestic and foreign tourism market, then lack of an adequate institutional framework (especially legislation) to ensure the coordination role of the state and greater involvement of local authorities in integrating rural development; poorly developed infrastructure; inadequate diversification of activities; domination of sectoral policies, etc. 
However, despite the fact that this form of tourism product is underdeveloped, rural areas of Serbia are considered to represent significant tourism potential for tourism development as well as for many other economic sectors of the country.

The quality of services is the main indicator of the achieved level of development of each form of tourist movement, and has been dealt with by many scientists, businessmen and other researchers, due to the fact that it has a great impact on customer satisfaction and loyalty, prices, business success and profitability (Klaus et al., 2013; Demirović et al., 2019). Given that there is no unique and generally accepted definition of the term quality, it can be said that quality is a measure of the usefulness of a particular product, the quality of which is being investigated (Fu et al, 2020). In order to survive in the tourism market, a rural product must provide adequate and necessary quality. Due to the increasing competition, it must be emphasized that in order to survive and further develop, or fight with competitors, the most important thing is to achieve acceptable quality for the consumer. Quality that meets his expectations, or quality that exceeds consumer expectations. It is the customer who sets the quality parameters and gives a final assessment of whether his requirements and expectations are fully and adequately fulfilled (Saleh et al, 1991; Lankford et al., 1994). The paper is based on an assessment of the quality of services provided in the rural area of the South Bačka District. There are limitations to achieving the optimal solution to the selection of criteria for deciding what is of good quality. The importance of the research work carried out by the authors is reflected in the assessment of the current state of the quality of rural tourism service, as well as the identification of key problems and finding corrective measures for improving the service and placing them in a better position. The approach used emphasizes the importance of assessing the quality of service before and after use. The aim is to present the situation in the right light, by conducting a research study of consumers or tourists themselves in the rural area of the South Bačka District. The work can contribute to the development of broader research on current issues. The structure of the work should be understandable to all who are not familiar with the problem.

\section{Literature Review}

\section{The concept and importance of rural tourism development - the situation in Serbia}

Rural development includes the activity and coordination of the whole system, all relevant economic and economic sectors as well as all social activities in the rural area. Some authors point out in their presentations that rural development is positioned above agrarian development by its size and complexity, since apart from the domain of agriculture, it implies the development of the non-agricultural sector, regardless of the fact that the agricultural sector is more dominant (Burns, 1996). In all rural development activities, emphasis is placed on interest in the environment, protected areas, sustainable tourism development (Baum, 2011; Marisa et al, 2011; Gajić et al., 2018). The key role of rural tourism is to preserve identity, heritage, tradition, in an adequate way, that creatively uses rural heritage, presenting it to visitors, through emphasizing the true value and importance of conservation. On the other hand, visitors to rural areas need to be offered a rural tourism product, with authentic, original and thorough experiences. The theme of rural tourism is very attractive and topical, as evidenced by the number of foreign and domestic authors who have dealt with it (Flisher et al., 2000; Jing et al., 2017). It must be emphasized that these are spaces of extraordinary values, special ecological areas, which carry the traditional culture and diversity of ethno-cultural heritage. Rural tourism is a very broad term that includes not only rural holidays but also all other tourist activities in rural areas, and takes place in areas that are mutually different in economic, sociocultural and demographic terms (Reichel, 1994; Fotiadis, 2011). All these differences are due to their geomorphological characteristics, population, economic structure, infrastructure, as well as the development potentials at their disposal. Rural tourism product includes both passive and active holidays, as well as all other activities in rural areas (Bramwell et al., 1994; Kunasekaran et al., 2011). Based on the research literature, it can be noted that this form of tourism is popular in many countries of the world. There are a number of studies that reveal that rural tourism has provided economic and social benefits in various rural areas of the world. Palmer 
(2010) pointed out that rural tourism businesses provided new sources of income for families living in remote rural areas. Rural tourism mainly refers to small family businesses and entrepreneurship entrepreneurs (Klaus, 2013). Jaakkola (2015) reported that rural tourism benefits local communities in terms of economic growth, socio-cultural development, provision of basic and non-essential services, and increasing living standards. The development of rural tourism is an important challenge for many rural areas in Serbia, especially when one considers the natural, cultural and historical heritage, gastronomy, manifestations, social characteristics of the people, as well as many other potentials of these areas (Yasuo, 2007). Certainly, such a tourism product is recognized as a major contribution to providing alternative sources of income for these areas, then diversifying the rural economy, increasing employment, and revitalizing many other sectors of the economy in Serbia (Demirović et al., 2017; Gajić et al., 2018). In certain areas of the country, there is a developed tourism product, rural tourism, which is developed through the integration of economic development of many of its sectors. Tourism has never occupied a significant place, nor has it ever been at the forefront of economic development in the South Bačka District (located in the northen part of the country). This is evidenced by tourism trends and expenditures, which do not participate in the generation of national income, although there are real chances and opportunities to be placed in a better place on the market due to the resource base and potential that the District possesses. South Bačka rural communities enjoy complementary support from local government in terms of general economic aid policies and targeted housing support. Peripheral rural areas are also considered repositories of older lifestyles and cultures that respond to the postmodern tourists' quest for authenticity. Encouraging the rural tourism of the District is increasingly becoming a daily plan development policy. Rising to meet demand, South Bačka's rural tourism offers an ideal market for small businesses, directly and indirectly bringing economic benefits to local businesses and fostering the development of connected small businesses (Gajić et al., 2018). Following the administrative decision of the local self-government unit to declare a settlement urban, it is stated that there are 6,158 settlements on the territory of the Republic of Serbia, of which 193 are urban (3.1\%) and 5,965 settlements are considered rural by automatism. According to the 2011 census report, there were 2,914,990 million inhabitants in rural areas of Serbia $\left(7,058,322\right.$ of the total population), while population density was 62 square $\mathrm{km}^{2}$. Today, it is estimated that more than 32,000 beds (registered and unregistered) in rural areas play a significant role in the rural tourism sector, and about 300 rural households with 8,000 beds provide catering services and provide more than 150,000 nights per year. It is estimated that about 10 billion dinars will be generated from the development of rural tourism, which is $16 \%$ of the total tourist turnover in Serbia (https://www.stat.gov.rs).

This study explores the current issue of the degree of development of rural tourism, through an examination of the quality of services provided in the Southwestern District. The authors will introduce the concept of service quality, followed by empirical consumer research. The gap between the expected service and the received service will be presented.

\section{Service quality as imperative to success}

In contemporary literature and research, quality is defined as the attitude of the user on the excellence of the tourist service or perhaps even on its superiority. Quality is certainly an attainable condition that reduces the gap between what is expected and what is obtained (Zhang et al., 2019). The level between what tourists expect and what they get in a tourist spot (Sharpley, 2014). Every organization strives to create the perfect way or gain the ability to meet expectations and exceed what every tourist consumer expects for the service they have paid for in advance (Akkbaba, 2006; Hyusunk et al., 2018). Continuous gathering of information by tourists and the market reduces defects and errors, satisfies demand, and thus quality reaches its expected level (Mason et al., 2000, Williams et al, 2001). The basis for achieving quality is also the constant adaptation to change, because the way to fight competitors is to change the way the business system works, at a faster pace than changes happening in the environment (Woo et al., 2018). The modern concept of quality puts the customer at the center of interest. Focusing on the consumer involves understanding their wants and needs, because quality means a satisfied consumer (Wang et al, 2008). Jing et al (2019), argues that 
the recession of rural areas in the world is the result of industrial civilization, but that in the postmodern world, rural areas have multiple functions, such as places for recreation, tourism, food and drink sales, etc. Many researches talk about tourists' satisfaction with their experience (Devesa et al., 2010; Kastenholz et al., 2012). Also, extensive research on the impact of tourism on rural development stands out ((Lindberg, et al., 1999; Wang et al., 2008; Williams et al., 2001).

It is very common to create Grönroos definition with two sub-lists in creating criteria for the quality of service in rural tourism, which means that equal conditions in different spaces can be judged differently in terms of quality. The service can be evaluated by different groups of people. Functional and technical aspects of quality can be evaluated differently, before and after using the service. The problem of perception is widely understood. One tourist may be somewhat responsive, while that service is perceived completely differently by another tourist. Grönroos (1990) emphasized the importance of the distinction between expected quality of service and actual quality of service. By comparing expected customer service with experienced customer service, an organization can determine whether the service standard exceeds, meets, or falls below the customer (Reichel et al, 1999).

Similar research is conducted in Israel, with the aim of pointing out the importance of exploring the expected and perceived value of the service in rural tourism. The authors of the aforementioned paper also refer to the concept of measuring the expected and obtained levels of service, more precisely the assessment of technical and functional dimensions through a questionnaire of 15 questions. Their research was based on Fleischer et al. (1993) study, which is simpler for smaller rural areas than SERVQUAL (Parasuraman, Zeithaml \& Berry, 1994), which is considered to be much more complicated. The use of perceived versus actual experiential tourism service makes the SERVQUAL model, which is intended to measure attitudes, based on the questionnaire responses, which also relate to customer satisfaction. A number of authors have been engaged in refining and assessing significance, critiquing the concept of the SERVQUAL questionnaire since 1993 (Brown, Churchill, \& Peter, 1993; Babakus \& Boller, 1992; Buttle, 1996; Carman, 1990; Ekinci, 2001; Ekinci \& Riley. 1998; Ekinci \& Riley, 2001). SERVQUAL service quality measurement is based on a questionnaire created by Parasuraman, Cajthamlova, and Barry in 1988 and represents the second level of their research work on service quality (Parasuraman, Berry, \& Zeithaml, 1991a). Following discussions on the conceptualization and operationalization of the quality construct (gap theory) (Parasuraman, Zeithaml, \& Berry, 1985; 1988) Do consumers really evaluate service quality in terms of expectations and perception? Does the five dimensions of SERVQUAL include the full range of service quality attributes? Do consumers also include evaluations of "service or service outcomes" in their assessment of service quality? These are just some of the many dilemmas that raise questions of external and construct validity.

\section{Research methodology and hypothesis setting}

In relation to the nature of the problem being investigated, objectives, tasks and assumptions, the research methodology is chosen. The subject of the research is the quality, satisfaction and future development of rural tourism in South Bačka. The district covers an area of $4,015 \mathrm{~km}^{2}$ and has a total population of 603,244. The municipalities included in the district are: Bač, Bačka Palanka, Bačka Petrovac, Bečej, Beočin, Srbobran, Vrbas, Žabalj, Novi Sad, Titel, Temerin and Sremski Karlovci, within which there are 77 settlements. The county seat is Novi Sad, the capital of the Autonomous Province of Vojvodina, the second largest in Serbia with a population of about 300,000 . The main aim and purpose of the research is to determine the existence of a relationship between the perceived and the expected level of quality of tourist service by collecting and processing primary and secondary data. The following methods were used in the research of the given problem: the bibliographic-speculative method was used to collect, analyze and interpret the obtained data or to structure the theoretical part of the paper. In the direct application of this method, the primary source of data consisted of relevant bibliographic units (books, reference journals). The first phase of the research involved available documentation or standard desk research. Existing literature, documentation, and review of 
relevant data from the available Master Plan for Sustainable Rural Development in Serbia were analyzed, as well as all other relevant sources that served as a basis for secondary research through comparative analysis. The authors also accessed direct data collection, processing and analysis. All data obtained were analyzed in SPSS software, version 23.00. The modified SERVQUAL questionnaire was applied to the survey, which presents 24 questions, grouped into five dimensions of the model (tangibility, reliability, responsibility, safety and empathy). With this methodology, 22 pairs of questions are usually formulated and questionnaires are distributed before use and after use of the service (Salch et al., 1991). A five-degree Likert scale is used to measure perceptions, from the extreme of degree 1, which is a completely negative answer, to a scale of 5 , which is the answer of complete agreement with a given fact. Research on the perception of quality of consumers of tourist services, implied a changed structure of questions in relation to expectations, before distribution.

Tab 1. Expectation items of the modified SERVQUAL model.

\begin{tabular}{|c|c|}
\hline Tangibility & $\begin{array}{l}\text { The tourist hospitality facility in rural areas should have a convenient location and good } \\
\text { accessibility. } \\
\text { The exterior of the building should be visually appealing (exterior) } \\
\text { * The interior of the building should be visually appealing } \\
\text { Brochures, brochures, menus, souvenirs in the facilities should be visually appealing. } \\
\text { The quality of food and drink should meet the needs of guests. } \\
\text { The assortment of food and drink should meet the needs of guests. } \\
\text { Food and beverage facilities should be clean and tidy } \\
\text { Rooms, bathrooms and toilets in the facility should be clean and tidy. } \\
\text { * Facility employees should act neatly } \\
\text { The tourist and catering facility should be able to organize entertainment programs for guests. } \\
\text { The tourist and catering facility should have adequate facilities for the recreation of guests. } \\
\text { Excursions should be organized at the tourist restaurant. }\end{array}$ \\
\hline Reliability & $\begin{array}{l}\text { * Facility employees should provide the service at the promised time. } \\
{ }^{*} \text { Facility staff should show understanding for guest problems. } \\
\text { * Facility staff should provide agreed upon services from the first meeting and beyond. }\end{array}$ \\
\hline Responsibility & $\begin{array}{l}\text { * Facility staff should always be ready to assist guests. } \\
{ }^{*} \text { Facility staff should be approachable and always ready to answer guest questions. } \\
{ }^{*} \text { Employees should respond promptly and promptly to guest requests. }\end{array}$ \\
\hline Security & $\begin{array}{l}{ }^{*} \text { Facility staff should always be friendly with guests. } \\
{ }^{*} \text { Facility staff should be knowledgeable and professionally meet guest requirements. } \\
\text { * The guests of the building should feel safe (personal and material security). }\end{array}$ \\
\hline Empathy & $\begin{array}{l}\text { The facility staff should give each guest individual attention. } \\
\text { * The employees of the facility should treat the guests honestly and compassionately. } \\
{ }^{*} \text { Facility staff should understand the specific needs of their guests. }\end{array}$ \\
\hline
\end{tabular}

* SERVQUAL model issues. Source: Survey adapted to rural facility survey based on the SERVPERC scale of the original SERVQUAL model by: Zeithaml, V. A., Parasuraman, A., Berry, L. L. (1990): Delivering Quality Service: Balancing Customer Perceptions and Expectations, The Free Press, New York, 181-183.

Table 1 shows the dimensions related to expectation, while the second part of the questionnaire contains statements, which are given in the first part of the questionnaire, as well, referring to the level of perceived performance of the service received.

Categorical variables are represented by absolute $(\mathfrak{f})$ and relative $(\%)$ frequencies. The central tendency of numerical features is represented by the arithmetic mean $(\mathrm{m})$, and the scatter by standard deviation (sd). Frequency distribution of numerical characteristics was examined by indicators of skewness and kurtosis. Since all variables were normally distributed, parametric statistics methods were used. A T - test of pairs was used to test for differences, with Pearson correlation coefficient $(r)$ also shown. The significance level selected is 0.05 . The results are presented in tables and graphs. Starting from the research problem, and considering the current research on the current topic, the main hypothesis as a subject of testing in order to prove it is:

\section{$H_{0}$ : There is no significant difference in quality value}




\section{$H_{a}:$ There is an established significant difference in quality value}

between expectation and perception pairs

\section{Research Results and Discussion}

Visitors to tourist facilities in the rural areas of the South Bačka District are the main sample of the survey. The survey was conducted between March and September 2019, on a sample of 710 respondents. A total of 1000 questionnaires were distributed, of which 710 , with complete answers, were taken into account in the analysis. The questionnaire was distributed in the following tourist and catering establishments of rural character, traditionally called salaš: Salaš 137 (Čenej), Brkin salaš (Čenej), salaš Volic (Čenej), Mitin salaš (Čenej), Salaš 84 (Čenej), Cvejin salaš ( Begeč), Salaš 264 (Bačka Topola), Mladina salaš (Begeč), Ethno Didina's house (Bač), Bucin salaš (Temerin), Babin salaš (Žabalj), Gnezdo (Bačka Palanka), Petrovac čarda (Bački Petrovac), Vujić salaš (Bečej), Milov salaš (Vrbas), salaš Tatić (Srbobran), salaš Stremen (Titel). A total of $58.4 \%$ of female respondents and $41.6 \%$ of men participated in the survey. The largest percentage of them belong to the age group 35$50(64.3 \%)$ and higher education $47 \%$. The largest number of research participants has a monthly income of 30,000 to 60,000 RSD.

Table 2 shows the results of the descriptive statistical analysis, where the values of the arithmetic mean and standard deviation are observed for all items that examine the respondents' expectations. It is observed that visitors had on average relatively high grades of expected quality for almost all services, which can be obtained in the given facilities of rural areas of South Bačka District. The exceptions are the exterior, interior, location or accessibility of the object, as well as the availability of souvenirs and other promotional material. The average expected values of these items are lower than the others.

Tab 2. Item analysis for expectation ( $m$ = arithmetic mean; $s d=$ standard deviation).

\begin{tabular}{|c|c|c|}
\hline Research items & $\mathrm{m}$ & $\mathrm{sd}$ \\
\hline $\begin{array}{l}\text { The tourist hospitality facility in rural areas should have a convenient location and good } \\
\text { accessibility. }\end{array}$ & 3.23 & 1,294 \\
\hline The exterior of the building should be visually appealing (exterior). & 3.66 & 1.136 \\
\hline The interior of the building should be visually appealing. & 3.62 & 1.380 \\
\hline Brochures, brochures, menus, souvenirs in the facilities should be visually appealing. & 3.90 & 1.185 \\
\hline The quality of food and drink should meet the needs of guests. & 4.05 & 0.970 \\
\hline The assortment of food and drink should meet the needs of guests. & 4.31 & 1.046 \\
\hline Food and beverage facilities should be clean and tidy. & 4.42 & 0.919 \\
\hline Rooms, bathrooms and toilets in the facility should be clean and tidy. & 4.50 & 0.789 \\
\hline Facility employees should act in an orderly manner. & 4.67 & 0.648 \\
\hline The tourist and catering facility should be able to organize entertainment programs for guests. & 4.42 & 0.931 \\
\hline The tourist and catering facility should have adequate facilities for the recreation of guests. & 4.67 & 0.619 \\
\hline Excursions should be organized at the tourist restaurant. & 4.58 & 0.699 \\
\hline Facility employees should provide the service at the promised time. & 4.33 & 1.094 \\
\hline Facility staff should show understanding for guest problems. & 4.31 & 1.147 \\
\hline Facility staff should provide agreed upon services from the first meeting to onwards. & 4.37 & 0.999 \\
\hline Facility staff should always be ready to assist guests. & 4.58 & 0.869 \\
\hline Facility staff should be approachable and always ready to answer guest questions. & 4.42 & 0.953 \\
\hline Employees should respond promptly and promptly to requests from guests. & 4.37 & 0.947 \\
\hline Facility staff should always be friendly with guests. & 4.36 & 0.953 \\
\hline The facility staff should have the knowledge and professional requirements of the guests. & 4.35 & 0.957 \\
\hline Guests of the property should feel safe (personal and material security). & 4.33 & 0.960 \\
\hline Facility staff should give each guest individual attention. & 4.34 & 0.963 \\
\hline The employees of the facility should treat the guests with honesty and compassion. & 4.28 & 0.975 \\
\hline Facility staff should understand the specific needs of their guests. & 4.25 & 0.986 \\
\hline
\end{tabular}

The highest value of the arithmetic mean is carried by the item. Employees should act in order $(m=4.62 ; s d=0.648)$. Then, the tidiness of rooms and other rooms was also rated as positive 
$(\mathrm{m}=4.50 ; \mathrm{sd}=0.789)$. High expectations of tourists are also in the services related to the organization of additional entertainment and recreational activities $(\mathrm{m}=4.67 ; \mathrm{sd}=0.619)$. The lower expectations of the spatial values of objects, which belong to the tangibility dimension, can already be noted in the table. The exterior was rated with an average score of $\mathrm{m}=3.66$ ( $\mathrm{sd}=1.136)$. Visitors had high expectations of the interior in the given objects of residence, which is also noticed by the average value obtained for the given item $\mathrm{m}=3.62$; $\mathrm{sd}=$ 1.380. The lowest rated score compared to all other dimensions of all dimensions mentioned is the convenient location and good accessibility of the building. The expected expectation values for the same item are $m=3.23$; $s d=1.294$. The empathy dimension, which contains questions related to the attitude of the employees towards the guests, shows a high level of expectations, since all the scores gave an average score above 4 . The employees should give individual attention to each guest, having the following values $\mathrm{m}=4.34$; $\mathrm{sd}=0.963$, and is also the highest expectation item in this dimension.

In the dimension of tangibility, the highest average grade is given by the item related to the orderliness of employees $(m=4.08 ; s d=1.336)$, while the worst-rated recreational opportunity for tourists $(\mathrm{m}=2.51$; $\mathrm{sd}=1.509)$. When considering the reliability dimension, the best average score was given by the employee's score showing understanding for guests with $\mathrm{m}=4.10$ and deviation $\mathrm{sd}=1.311$, while the lowest average rating was given by the item related to service delivery at the promised time $(m=3.46 ; \mathrm{sd}=1.455)$. The responsibility dimension contains three questions, where on average the best-rated prompt response service is partially positive $(\mathrm{m}=4.03$; $\mathrm{sd}=1.427)$. The dimension of security dimension, which speaks of the kindness of the staff, is on average rated $m=4.22$ points and deviation $s d=1.235$. The worst rated service was the feeling of security $(m=3.66$; $s d=1.313)$. The object staff understands the specific needs of the guests, from the empathy dimension, carries the highest marks $(m=4.44$; $s d=1.073)$.

Tab 3. Item analysis for the perception variable ( $m=$ arithmetic mean; sd = standard deviation).

\begin{tabular}{|l|c|c|}
\hline \multicolumn{1}{|c|}{ Research Aitems } & $\mathrm{m}$ & $\mathrm{sd}$ \\
\hline Rural tourism facility has convenient location and good accessibility. & 3.26 & 1.240 \\
\hline The exterior of the building is visually appealing (exterior) & 2.98 & 1.548 \\
\hline The interior of the building is visually appealing & 3.52 & 1.446 \\
\hline Brochures, brochures, menus, souvenirs in the buildings are visually appealing. & 2.60 & 1.215 \\
\hline The quality of the food and drink meets the needs of the guests. & 3.88 & 1.352 \\
\hline An assortment of food and beverages meets the needs of guests. & 3.80 & 1.434 \\
\hline Food and beverage rooms are clean and tidy. & 3.09 & 1.579 \\
\hline The rooms, bathrooms and toilets of the property are clean and tidy. & 3.42 & 1.603 \\
\hline The facility's employees are neat. & 4.08 & 1.336 \\
\hline $\begin{array}{l}\text { The tourist and catering facility provides the opportunity to organize entertainment programs for } \\
\text { guests. }\end{array}$ & 3.65 & 1.557 \\
\hline In the tourist and catering facility there are adequate facilities for recreation of guests & 2.51 & 1.509 \\
\hline Excursions are organized in the tourist and catering facility & 3.66 & 1.627 \\
\hline Facility employees provide the service at the promised time. & 3.46 & 1.455 \\
\hline Facility employees show understanding for guest problems. & 4.10 & 1.311 \\
\hline The facility's employees provide agreed upon services from the first meeting and beyond. & 3.74 & 1.311 \\
\hline Facility employees are always ready to assist guests. & 3.99 & 1.291 \\
\hline The facility staff are approachable and always ready to answer guests' questions. & 3.78 & 1.527 \\
\hline At the request of guests, employees respond quickly and without delay. & 4.03 & 1.427 \\
\hline The facility staff are friendly with the guests. & 4.22 & 1.235 \\
\hline $\begin{array}{l}\text { The facility staff have the knowledge and professional requirements to meet guests' } \\
\text { requirements. }\end{array}$ & 3.84 & 1.316 \\
\hline Guests of the property feel safe (personal and material security). & 3.66 & 1.313 \\
\hline The facility's employees give each guest individual attention. & 3.98 & 1.223 \\
\hline The employees of the facility treat the guests honestly and compassionately. & 3.73 & 1.295 \\
\hline Facility staff understand the specific needs of their guests. & 4.44 & 1.073 \\
\hline
\end{tabular}




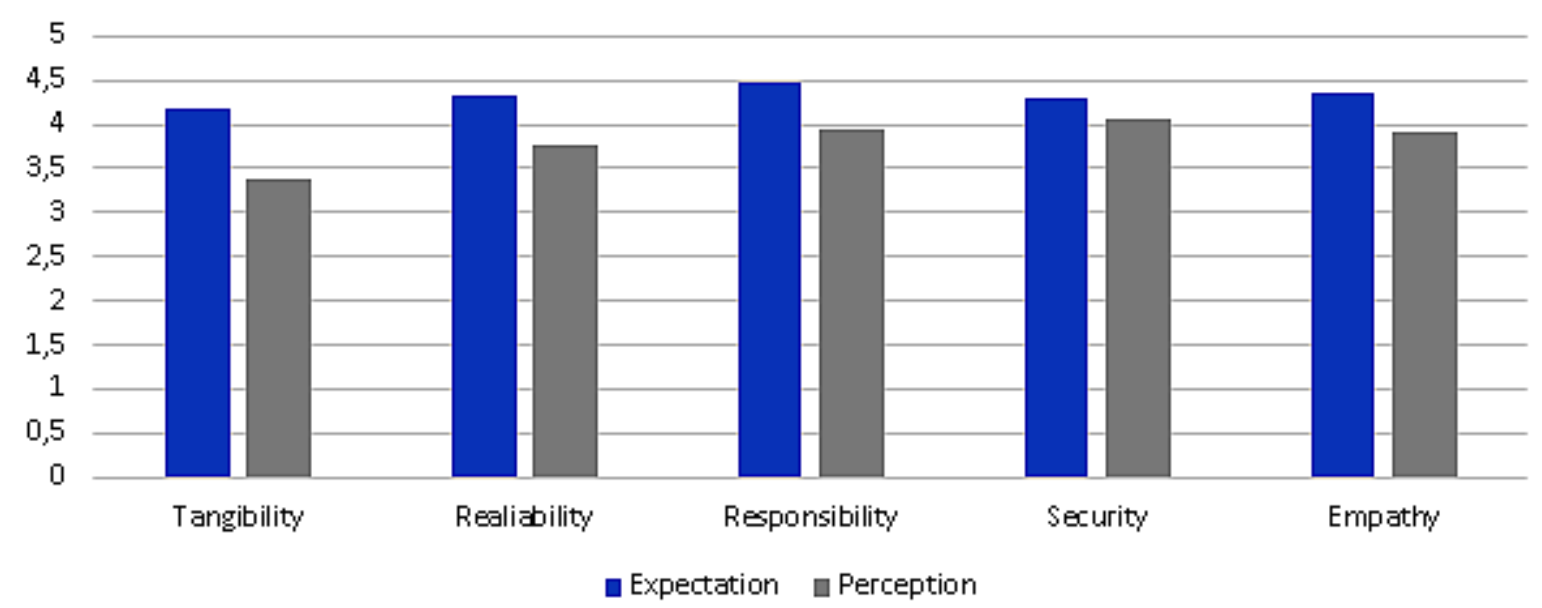

Fig 1. Average values of respondents' expectations and perceptions by dimensions.

The figure 1 shows the average values for expectation and perception of given dimensions. All dimensions carry partially positive ratings when it comes to the value of expectations, except for responsibility with a completely positive rating, while for the perception of dimensions the situation is slightly different. It can be observed that the expectation of the responsibility dimension carries the highest average score of 4.46, while the perception of the same dimension is 3.93. Based on the obtained indicators, it is concluded that the tangibility dimension was estimated with the lowest average score both at expectations (4.17) and at perception (3.37).

Tab 4. Pair correlation coefficient Expectation / Perception.

\begin{tabular}{|l|l|c|c|}
\hline \multicolumn{1}{|c|}{ Dimension } & \multicolumn{1}{c|}{ Pair } & $r$ & $p$ \\
\hline Tangibility & Expectation - Perception & 0.167 & $0.000^{*}$ \\
\hline Reliability & Expectation - Perception & -0.369 & $0.000^{*}$ \\
\hline Responsibility & Expectation - Perception & -0.070 & 0.061 \\
\hline Security & Expectation - Perception & 0.113 & $0.002^{*}$ \\
\hline Empathy & Expectation - Perception & -0.090 & $0.016^{*}$ \\
\hline
\end{tabular}

$* p<0,05$ statistically significant

Table 4 shows the results of the correlation analysis of dimensions of expectations and perceptions. Based on the results, it is concluded that there is a statistically significant correlation between expectations and perceptions. The correlation between expected and perceived tangibility is weakly positive $(r=0.167 ; p=0.000)$. The expected values of the tangibility dimension and its perception are moving in the same direction at the same time. The correlation of expected and perceived reliability is moderately strong, negative $(r=-0.369$; $p=0.000$ ). This information indicates that a high expectation of reliability is accompanied by low perceptions of the same and vice versa. In the couple, expectation / perception, responsibility dimension, no significant correlation ( $p>0.05$ ). The dimension of security expectation correlates poorly with the dimension of security perceptions $(r=0.113 ; p=0.002)$. There is a functional relationship between these two dimensions, which is defined as a weak positive, with the expected and perceived values of the security dimension moving in the same direction. The results of the correlation analysis indicate that there is not a strong relationship between expectation of empathy and perception of empathy $(r<0.1)$, and although the statistical significance of the pair $(p=0.016)$ is observed, this relationship is not strong enough.

Starting from the fact that the pairs have a normal distribution, the t test of the arithmetic means of the two large samples and the $t$ test of the paired samples was applied to test the hypotheses. 
Tab 5. T test of statistical significance of difference of arithmetic mean of expectation and perception (SERVQUAL gap).

\begin{tabular}{|l|c|c|c|c|c|c|c|c|c|}
\hline \multicolumn{1}{|c|}{ Dimension } & $\mathbf{m}_{\mathbf{e}}$ & $\mathbf{s d}$ & $\mathbf{m}_{\mathbf{p}}$ & $\mathbf{s d}$ & $\mathbf{m}_{\mathbf{p}}-\mathbf{m}_{\mathbf{e}}$ & $\mathbf{t} \mathbf{( 7 1 6 )}$ & $\mathbf{p}$ & $\mathbf{L 9 5 \%}$ & $\mathbf{U 9 5 \%}$ \\
\hline Tangibility & 4.17 & 0.289 & 3.37 & 0.378 & -0.797 & 49.034 & $0.000^{*}$ & 0.765 & 0.829 \\
\hline Reliability & 4.33 & 0.673 & 3.77 & 0.747 & -0.566 & 12.901 & $0.000^{*}$ & 0.480 & 0.652 \\
\hline Responsibility & 4.46 & 0.590 & 3.93 & 1.100 & -0.526 & 10.983 & $0.000^{*}$ & 0.432 & 0.620 \\
\hline Security & 4.29 & 0.835 & 4.05 & 0.808 & -0.238 & 5.825 & $0.000^{*}$ & 0.157 & 0.318 \\
\hline Empathy & 4.35 & 0.827 & 3.90 & 0.880 & -0.443 & 9.404 & $0.000^{*}$ & 0.350 & 0.534 \\
\hline Total & 4.32 & 0.407 & 3.81 & 0.320 & -0.514 & & & & \\
\hline
\end{tabular}

${ }^{*} m_{p}=$ the arithmetic value of a pair of perceptions; $m_{e}=$ the arithmetic value of the expectation pair; $m_{p}-m_{e}=$ the value of the gap of expectations and perception; $t(716)=T$ value and degree of freedom; $p=$ statistical significance; $\mathrm{Cl}=$ confidence interval (L (lower), $\mathrm{U}$ (upper)).

Table 5 shows the arithmetic means for the dimensions of expectations and perceptions, and the gap created between the dimensions of expected and perceived quality of service. It is observed that the difference between the expected and perceived quality in each dimension is negative. Expectations, dimensions of tangibility, are on average very well rated, while perception is indifferent $\left(m_{e}=4.17, \mathrm{sd}=0.289 ; \mathrm{m}_{\mathrm{p}}=3.37, \mathrm{sd}=0.378\right)$. A score difference of 0.797 proved to be statistically significant and confirmed by a $95 \%$ confidence interval $(t=716$, $\mathrm{p}<0.05 \mathrm{Cl} 95 \%(\mathrm{~L}=0.765 ; \mathrm{U}=0.829))$. In other words, the expectation of tangibility is significantly higher than the perception of the same in the average respondent. The average expectation of the reliability dimension was partially positive $\left(m_{e}=4.33\right.$, $\left.s d=0.673\right)$. However, the average value of perception at reliability also bears a partially positive mark $\mathrm{m}_{\mathrm{e}}=3.77 \mathrm{(sd}=$ 0.747). $<0.05 ; \mathrm{Cl} 95 \%(\mathrm{~L}=0.480 ; \mathrm{U}=0.652)$. The value of the arithmetic mean on the expectation responsibility subscale is $m_{e}=4.46(\mathrm{sd}=0.590)$, while the same value on the perception responsibility subscale is $m_{p}=3.93$. A score difference of 0.526 was found to be statistically significant $(\mathrm{p}<0.05 ; \mathrm{t}=716, \mathrm{Cl} 95 \%)$. The arithmetic mean of expectations, the dimensions of security, as well as the perception of the same dimension, carry a partly positive rating. Although the difference between the points was only 0.238 , it still proved statistically significant $(p<0.05)$. The expectation of the empathy dimension was rated partly positive (me $=4.35$, sd $=0.827$ ), and the perception of empathy gave a rating of $3.90(\mathrm{sd}=0.880)$. The difference in the average between expectations and the perception of empathy $\left(m_{p}-m_{e}=0.443\right)$ was estimated statistically significant, confirming the value of $\mathrm{p}<0.05$, and the confidence interval $(\mathrm{t}=716$; $\mathrm{Cl} 95 \%(\mathrm{~L}=0.350 ; \mathrm{U}=0.534))$.

Based on the presented values and differences of arithmetic means for the dimensions of the couple's expectation and perception, it is concluded that tourists with all factors had significantly higher expectations. The realized value of the t test, for a given number of degrees of freedom and a significance threshold $p<0.05$, with a confidence interval of $95 \%$, indicates that the null hypothesis is rejected and confirmation is given by the alternative hypothesis, that there is a statistically significant difference between the arithmetic values of the expectation pairs and perception. Many world studies show similar results, that there is a gap between expected and obtained services, especially when it comes to rural tourism product, which is only in its initial stage of marketing. The South Bačka District is not a destination that with its rural product occupies a significant place in the regional and world tourism market. Similar research was conducted in 1999 by Arie Ratchel, Oded Lowengart and Ady Milman, in Israel. According to their research on a sample of 205 respondents, gaps between expectations and perception are noticeable. Namely, all services received average marks above three, with the highest rated employee-to-tourist ratio and the worst additional recreational activities. The average values of the arithmetic mean for all the expectation and perception patterns indicate that there are differences between the dimensions. Then, in 2018, a survey on a similar topic of measuring service quality in rural areas was conducted by Hyunsuk Choi, Saehya Ann, Kwang, Woo Lee, Duk Byeong Park, South Korea, in a sample of 442 respondents. The same model was applied to research in rural Romania, where Julia Muresan, Ileana Andreica and Felix Arion, 2010, with a relatively small sample of 50 survey participants, found similar results in rural tourism product development and the degree of difference between expectations. and perception. 


\section{Conclusion}

Rural areas in Serbia, as well as in the South Bačka District, are not at an enviable level when it comes to tourist visits and the quality of services provided. There are major problems facing rural areas. Some of them are depopulation of villages in Serbia, poorly developed communal infrastructure and low productivity of the rural economy. Also, the low level of education of the rural population, as well as minimal efforts to preserve the historical and original rural environment, are the main obstacles hindering further development (Gajić et al., 2018). It is noted that current laws, standards and regulations do not significantly contribute to overcoming these problems. The low level of integration and partnership between tourism organizations and local governments influences business inefficiencies and degrades the tourist attractiveness of rural areas. The current level of competitiveness of the South Bačka District in the rural sphere is not good, which is based on an assessment of all key success factors.

The data in the paper specifically reflect the situation in the South Bačka District, but may be valid nationwide. The authors of the paper were based on determining the degree of existing quality. The aim of the research is conceptualized in accordance with the scientific and social contribution. The focus of the study was put on the correlation between expected and perceived service, as an indicator of the current state of service quality. The results of the statistical analysis of satisfaction show that there are significant differences in service expectation and perception. When assessing each quality factor, tourists had significantly higher expectations than those they received during their stay in rural tourist facilities. The importance of the research carried out by the authors is reflected in the assessment of the current quality of the rural tourism product. Emiric research corroborates theoretical data, and emiricisation of data can create new theories in the domain of service quality. By noticing correlation differences between expected and perceived service, and mistakes and deficiencies in quality, it is possible to implement corrective measures in order to improve business and position on the tourist market. It can be safely confirmed after research that the greatest weakness of rural tourism is the lack of interest or inability to assess the needs and demands of tourists. Assessing their needs and requirement is the key to success. Therefore, the authors have begun evaluating their satisfaction after using the service, but with the information obtained before the service used is more accurate.

Regarding the limiting factors of the research, it can be said that there were difficulties in assessing consumers, when completing the survey before and after using the service. Many of them did not show the will to give answers after the service used. In addition, the sample was exclusively for domestic tourists. It is very important that the work had an exploratory character, with only 710 respondents interviewed, without specific techniques to ensure a representative sample. Rural tourism in the South Bačka District is only part of what Serbia has to offer, and certainly the number of respondents is not sufficient to assess the state of the whole country, but it is useful for future research on the topic. What needs to be approached is to explore the attitudes and satisfaction of tourists after their second or third visit. In this case, the assumption is that the level of satisfaction would increase as they return to the same destination more than once. What the theory claims is that tourism in the South Bačka District is not at an adequate and satisfactory level in terms of quality, as confirmed by the research data obtained.

\section{Acknowledgments}

The research was supported by Ministry of Education, Science and Technological Development, Serbia (Grant No. III 47007). 
[1] Akbaba, A. (2006). Measuring service quality in the hotel industry: A study in a business hotel in Turkey. Hospitality Management 25, 170-192. DOI: 10.1016/j.ijhm.2005.08.006.

[2] Baum, S. (2011). The Tourist Potential of Rural Areas in Poland. Eastern European Countryside 17, 107-135. DOI: 10.2478/v10130-011-0006-z.

[3] Bramwell, B. \& Lane, B. (1994). Rural tourism and sustainable rural development. London: Channel View Books.

[4] Burns, D. (1996). Attitude towards tourism development. Annals of Tourism Research 23, 935-938. DOI: 10.1016/0160-7383(95)00115-8.

[5] Demirović, D., Berjan, S., Milentijević, N., El Bilali, H. \& Syromiatnikova, Y. (2019). Exploration of tourist motivation and preferred activities in rural areas. Journal of the Geographical Institute, „Jovan Cvijić“ SASA 69(1), 29-37. DOI: 10.2298/IJGI1901029D.

[6] Demirović, D., Kosić, K., Surd, V., Zunić, L. \& Syromiatnikova, Y. (2017). Application of tourism destination competitiveness model on rural destinations. Journal of Geographical Institute, „Jovan Cvijić“ SASA 67(3), 79-295. DOI: 10.2298/IJGI1703279D.

[7] Devesa, M., Laguna, M. \& Palacios, A. (2010). The role of motivation in visitor satisfaction: Empirical evidence in rural tourism. Tourism Management 31(4), 547-552. DOI: 10.1016/j.tourman.2009.06.006.

[8] Filipe, M. \& Mascarenhas, J. M. (2011). Abandoned villages and related geographic and landscape context: guidelines to natural and cultural heritage conservation and multifunctional valorization. European Countryside, 3(1), 21-45. DOI: 10.2478/v10091-0110002-3.

[9] Fleischer, A. \& Tchetchik, A. (2005). Does rural tourism benefit from agriculture? Tourism Management 26 (4), 493-501. DOI: 10.1016/j.tourman.2003.10.003.

[10] Flisher, A. \& Felsenstein, D. (2000). Support for rural tourism: Does it make a dif- ference? Annals of Tourism Research 21(4), 180-194. DOI: 10.1016/S0160-7383(99)00126-7.

[11] Fotiadis, A. (2011). The role of tourism in rural development through a comparative analysis of a Greek and a Hungarian rural tourism area [PhD theses]. University of Pécs.

[12] Fu, X., Riddersataat, J. \& Jia, H. (2020). Are all tourism markets equal? Linkages between market-based tourism demand, quality of life, and economic development in Hong Kong. Tourism Management, 77, Article 104015. DOI: 10.1016/j.tourman.2019.104015.

[13] Gajić, T., Vujko, A., Penić, M., Petrović, M. \& Mrkša, M. (2018). Examination of Regional Disparity in the level of Tourist Offer in Rural Clusters of Serbia. Economic of Agriculture, 3, 911-929. DOI: 10.5937/ekoPolj1803911G.

[14] Gajić, T., Penić, M., Vujko, A. \& Petrović, M. D. (2018). Development Perspectives of Rural Tourism Policy - Comparative Study of Rural Tourism Competitiveness Based on Perceptions of Tourism Workers in Slovenia and Serbia. Eastern European Countryside, 24(1), 144-154. DOI: 10.2478/eec-2018-0007.

[15] Gajić, T., Vujko, A., Petrović, M. D., Mrkša, M. \& Penić, M. (2018). Examination of regional disparity in the level of tourist offer in rural clusters of Serbia. Economic of agriculture 65(3), 911-929. DOI: 10.5937/ekoPolj1803911G.

[16] Hyunsuk, C., Saehya, A. \& Duk Byeong, P. (2018). Measuring Service Quality of Rural Accommodations. Sustainability, 2018, 10(2), 1-15. DOI: 10.3390/su10020443.

[17] Jaakkola, E., Helkkula, A. \& Aarikka, L. (2015). Service Experience co-creation: Conceptualization, implications, and future research directions. Journal of Service Management 26(2), 182-205. DOI: 10.1108/JOSM-02-2015-0045. 
[18] Jing, G. \& Bihu, W. (2017). Revitalizing traditional villages through rural tourism: A case study of Yuanjia Village, Shaanxi Province. China Tourism Management 63, 223-233. DOI: 10.1016/j.tourman.2017.04.003.

[19] Klaus, P. \& Maklan, S. (2013). Towards a Better Measure of Customer Experience. International Journal of Market Research 55(2), 227-246. DOI: 10.2501/IJMR-2013-021.

[20] Kunasekaran, P., Ramachandran, S., Yacob, M. R. \& Shuib, A. (2011). Development of Farmers' Perception Scale on Agro Tourism in Cameron Highlands, Malaysia. World Applied Sciences Journal 12, 10-18.

[21] Lankford, S. V. \& Howard, D. R. (1994). Revisiting TIAS. Annals of Tourism Research 21(4), 829-831. DOI: 10.1177/004728759403200374.

[22] Lindberg, K., Dellaert, B. G. C. \& Rassing, C. R. (1999). Resident tradeoffs: A choice modeling approach. Annals of Tourism Research 26(3), 554-569. DOI: 10.1016/S01607383(99)00009-2.

[23] Luloff, A. E., Bridger, J. C., Graefe, A. R., Saylor, M., Martin, K. \& Gitelson, R. (2001). Factors for Success in Rural Tourism Development. Journal of Travel Research 40(2), 132-138. DOI: 10.1177/004728750104000203.

[24] Kastenholz, E., Carneiro, M. J., Marques, C. P. \& Lima, J. (2012). Understanding and managing the rural tourism experience-the case of a historical village in Portugal. Tourism Management Perspectives 4(4), 207-214. DOI: 10.1016/j.tmp.2012.08.009.

[25] Mason, P. \& Cheyne, J. (2000). Residents' attitude to proposed tourism development. Annals of Tourism Research 27, 391-411. DOI: 10.1016/S0160-7383(99)00084-5.

[26] Parasuraman, A. \& Zeithaml, V. A., Berry, L. L. (1985). A Conceptual Model of Service Quality and its Implications for Future Research. Journal of Marketing 49(4), 41-50. DOI: $10.2307 / 1251430$.

[27] Parasuraman, A. \& Zeithaml, V. A., Berry, L. L. (1988). SERVQUAL: A multiple-item scale for measuring consumer perceptions of service quality. Journal of Retailing 64(1), 12-40.

[28] Petrović, M., Vujko, A., Gajić, T., Vuković, D., Radovanović, M., Jovanović, J. \& Vuković, N. (2018). Tourism as an Approach to Sustainable Rural Development in Post-Socialist Countries: A Comparative Study of Serbia and Slovenia. Sustainability 10(54), 2-14. DOI: $10.3390 /$ su10010054.

[29] Reichel, A., Lowengart, O. \& Milman, A. (1999). Rural tourism in Israel: service quality and orientation, Tourism Management 21(5)), 451-459. DOI: 10.1016/S0261-5177(99)00099-0.

[30] Saleh, F. \& Ryan, C. (1991). Analysing Service Quality in the Hospitality Industry Using the SERVQUAL Model. The Service Industries Journal 11(3), 324-343. DOI: $10.1080 / 02642069100000049$.

[31] Sharpley, R. (2014). Host perceptions of tourism: A review of the research. Tourism Management 42, 37-49. DOI: 10.1016/j.tourman.2013.10.007.

[32] Wang, Y. S. \& Pfister, R. E. (2008). Residents' attitudes toward tourism and perceived personal benefits in a rural community. Journal of Travel Research 47(1), 84-93. DOI: $10.1177 / 0047287510394193$.

[33] Williams, J. \& Lawson, R. (2001). Community issues and resident opinions of tourism. Annals of Tourism Research 28(2), 269-290. DOI: 10.1016/S0160-7383(00)00030-X.

[34] Woo, E., Uysal, M. \& Sirgy, M. J. (2018). Tourism Impact and stakeholders' quality of life. Tourism Management 42(2), 260-286. DOI: 10.1177/1096348016654971.

[35] Yasuo, O. (2007). Multifunctionality and rural tourism: A perspective on farm diversification. Journal of International Farm Management 4(1), 1-23.

[36] Zeithaml, V. A., Parasuraman, A. \& Berry, L. L. (1990). Delivering Quality Service: Balancing Customer Perceptions and Expectations. New York: Free Press. 
[37] Zhang, C. X., Pearce, P. \& Chen, C. (2019). Not losing our collective face: Social identity and Chinese tourist's reflecyions on uncivilised behaviour. Tourism Management 73, 7182. DOI: 10.1016/j.tourman.2019.01.020.

\section{Other sources}

[38] Statistical Office of the Republic of Serbia. 